\title{
Students' Creative Thinking in Posing Mathematical Problem with Different Context
}

\author{
Ratih Maharani, Tatag Yuli Eko Siswono, and Endah Budi Rahaju \\ Program Pascasarjana Department of Mathematics, Universitas Negeri Surabaya, Surabaya, East Java, Indonesia \\ ratihmaharani16070785044@mhs.unesa.ac.id
}

\begin{abstract}
Learning mathematical is believed to enhance student's creative thinking. Problem posing can be a form of training in creative thinking. Problem posing requires that the student be creative and use the mathematical knowledge that has been obtained to connect several concepts. Differences context of the contextual problem shows that mathematics can be applied in various problems in everyday life. The sample was the students of VIIIA class of the SMP Al Islamiyah. All students had to complete a test which was posing mathematical problem with different context. Based on problem posing test, students are group into four categories. The categories are personal, societal, occupational, and scientific context. In order to find out the students' creativity thinking, an analysis of problem posing test based on fluency, flexibility, novelty, and categorized based on creative thinking level (CTL). The results showed that CTL 2's student met novelty in personal context, CTL 1's student met fluency in societal context, CTL 3's student met fluency and flexibility in occupational context, while CTL 4's student met all components in scientific context. The results are affected by students' familiarity context. The findings of this study, student's problem posing creativity are depends on their familiarity in context that related to their real-life.
\end{abstract}

Keywords-Creative thinking, Problem posing, Difference context.

\section{INTRODUCTION}

Creative thinking is needed to create a new idea. Creative thinking is defined as a combination of logical and divergent thinking based on intuition under consciousness [1]. Creative thinking occurs when someone intentionally produces a new product or when someone is doing the task [2]. Creative thinking is based on a fundamental principle where a new idea is formed from a combination of old ideas in a new way [3]. The simplest way is to add, replace, or reduce the ideas. Students' would think to look for the ideas that are used to posed an solve problem [4].

The students' experience would be incomplete if they never had a chance to problem posing and solve it themselves [5]. Problem posing was a task given to students based on the information or situations in which they had to pose, make, and solve the problem themselves [6,7]. The teachers could provide task to do problem posing when students ever completed similar problems.

Most students considered that the story question was a challenging one because they failed to solve the question correctly [8]. The students' weakness in solving the story question was on the ability in understanding question and planning solution so that creative thinking was needed [9]. To improve the students' creative thinking, they were asked to submit a story question. The question was in term of modified calculation materials like a story related with daily life [10]. Thus, using the daily life context could be used in problem solving [11]. Context is the information that is contained and related with daily life $[12,13]$ The PISA mathematics questions were set in four different such as personal, occupational, societal, and scientific context [14]. Personal context related to the daily life of students and their families. Occupational context related to the situation and condition in working place. Societal context related to the social life in the communities in which the students lived. The last was scientific context that related to the use of mathematics in science and technology. The different contexts in questions enabled students to pose the unlimited stories in preparing new ideas.

Therefore, this study was aimed to describe students' creative thinking in posing stories with different contexts. The components used to assess creative thinking were flexibility, fluency and novelty demonstrated through the creative thinking level $[6,15]$

\section{METHOD}

The research is conducted by $8^{\text {th }}$ grade student selected a class from 5 classes available which is $8 \mathrm{~A}$, consist of 13 boys and 19 girls. The subjects of the study were 4 of $8 \mathrm{~A}$, in which the four students represented each context of question. The instrument used to collect the data was tests on story question based on personal, societal, occupational, and scientific contexts. The test was given in 60 minutes. The data were analysed based on components of flexibility, fluency, and novelty, as well as the creative thinking level (CTL) $[6,15]$. The subjects were selected based on their answers that met at least one component of a creative thinking assessment. The indicators of CTL that is used in this study explain in Table 1.

TABLE I. INDICATORS OF CTL

\begin{tabular}{|c|c|}
\hline Level & Characteristic of Creative Thinking Level \\
\hline $\begin{array}{c}\text { Level } 4 \\
\text { (Very }\end{array}$ & $\begin{array}{c}\text { Student satisfied all components of creative thinking or } \\
\text { only flexibility and novelty in posing problem }\end{array}$ \\
\hline $\begin{array}{c}\text { Levelive) } \\
\text { (Creative) }\end{array}$ & $\begin{array}{c}\text { Students were fluent and then they were flexible or } \\
\text { demonstrate novelty }\end{array}$ \\
\hline
\end{tabular}


TABLE I. CONT.

\begin{tabular}{|c|c|}
\hline Level & Characteristic of Creative Thinking Level \\
\hline Level 2 & Student were able to show flexibility or novelty in \\
(Quite & posing problems without fluency \\
Creative) & \\
\hline Level 1 & Students were able to show fluency without novelty \\
(Almost & and flexibility in posing problem \\
Not & \\
Creative) & \\
\hline Level 0 & Students were not able to show any components of \\
(Not & creativity \\
Creative) & \\
\hline
\end{tabular}

Adapted from reference [1]

\section{RESULT}

Data were analyzed based on components of flexibility, fluency, and novelty, as well as students' result of creative thinking level (CTL). The result showed that there were 13 students who posed the story question based on personal context, 7 students for societal and scientific contexts, and 5 students for occupational context. Mostly, the students' results on posing story question fulfilled only component of flexibility by three different questions. The subject studied in the question was the highest creative thinking level for each context. The results of the story question showed each component as follows; personal context met CTL 2, societal context met CTL 1 , occupational context met CTL 3 , while scientific context met CTL 4.

\section{A. Student in Personal Context}

A Student in personal context posed three problems and solution shows in Figure 1
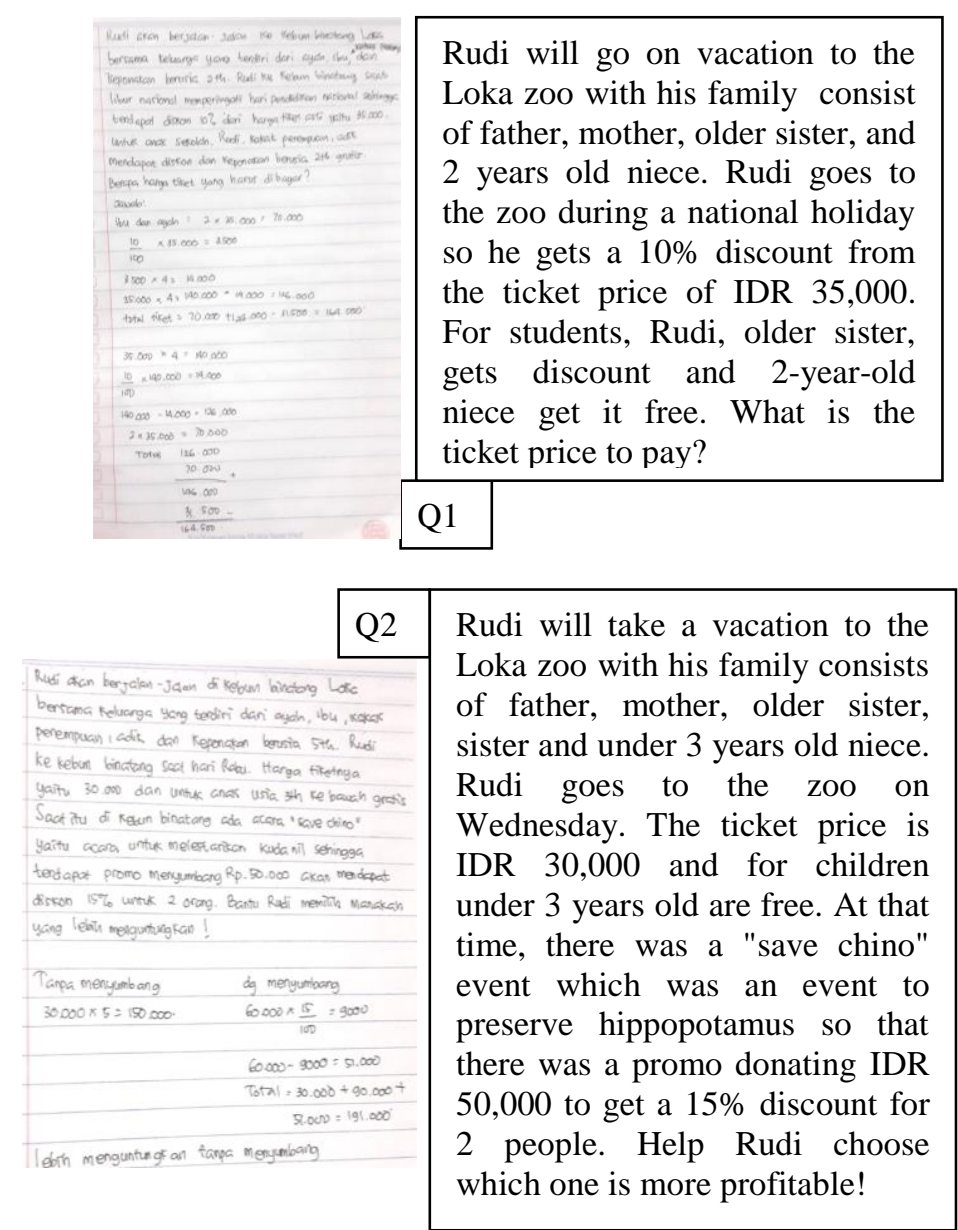

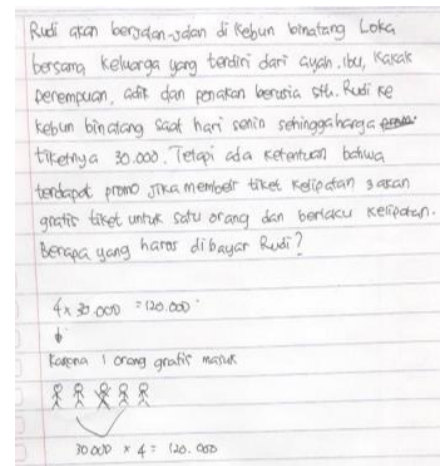

Rudi will take a vacation to the Loka zoo with his family consists of father, mother, older sister, sister and 5 years old niece. Rudi goes to the zoo on Monday so the ticket price is IDR 30,000 . But there is a promo if you buy a three tickets, you will get one ticket for free. How much should Rudi pay?

Figure 1: Problems and Solutions Posed by Student in Personal Context

The student posed the first mathematics problem (Q1) about zoo entrance ticket after getting a discount. There was information that the ticket was free for children under 3 years old. The student still calculated the total price of 6 tickets including tickets for children. Then, total calculation reduced by total prices for free tickets of children. The answer was true. Student performed two ways calculation but difference in completing the answers. Therefore, student did not meet the component of flexibility.

The student posed the second question (Q2) about choosing cheaper entrance ticket. There was information that the ticket was free for children under 3 years old. First step, student calculated the price without promo. The second step, students looked for the information about discounts for two people then calculated the final result. Student's calculation showed that the price without promo was the cheapest. While the second question had different concept from the first question, indicating that it met component of novelty.

The student posed the third question (Q3) about entrance ticket after promo. Student worked in two different ways but the answers were also the same. The answer that student got was wrong because it only calculated the price of five tickets without paying on information about free ticket for children under 3 years old like question in number one and two. Therefore, it did not meet component of fluency because only posing two questions. Posing personal context on question story was categorized in CTL 2 because it only fulfilled component of novelty.

\section{B. Student in Societal Context}

A Student in societal context posed three problems and solution shows in Figure 2 

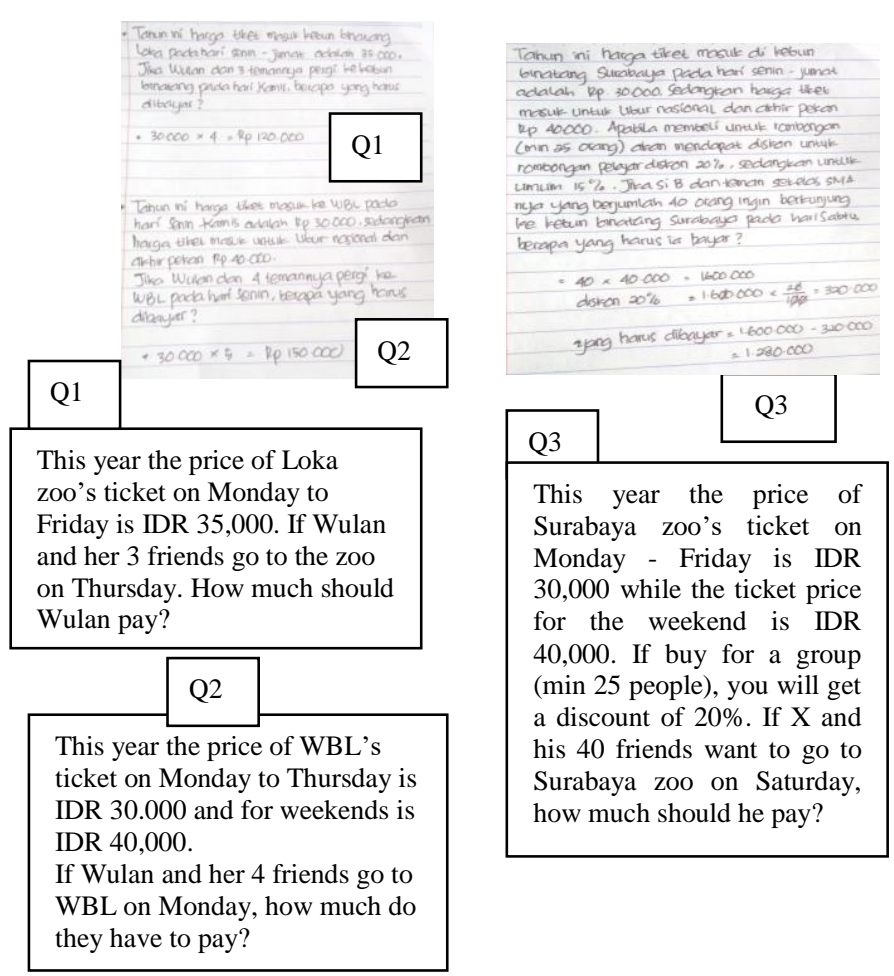

Figure 2: Problems and Solutions Posed by Student in Societal Context

The student posed first question (Q1) about zoo entrance ticket price. Student did not attach the information on the given story. Student is not able to finish it using different ways. The first and second questions (Q1 \& Q2) were not significantly different. In the second question, the student gave more information but the question was similar to first question. Student also completed the question only using one way.

The student posed third question (Q3) about ticket prices after discount. Student posed a story question by changing the subject and number. Student solved the problem using one way, namely looking for discount first and then minimizing the normal ticket price. The student who posed story question based societal context met component fluency, when posing only three questions. Student did not meet the component of novelty because the context of the question did not change. Posing societal context on question story was categorized in CTL 1 because it only fulfilled component of novelty.

\section{Student in Occupational Context}

A Student in occupational context posed three problems and solution shows in Figure 3.
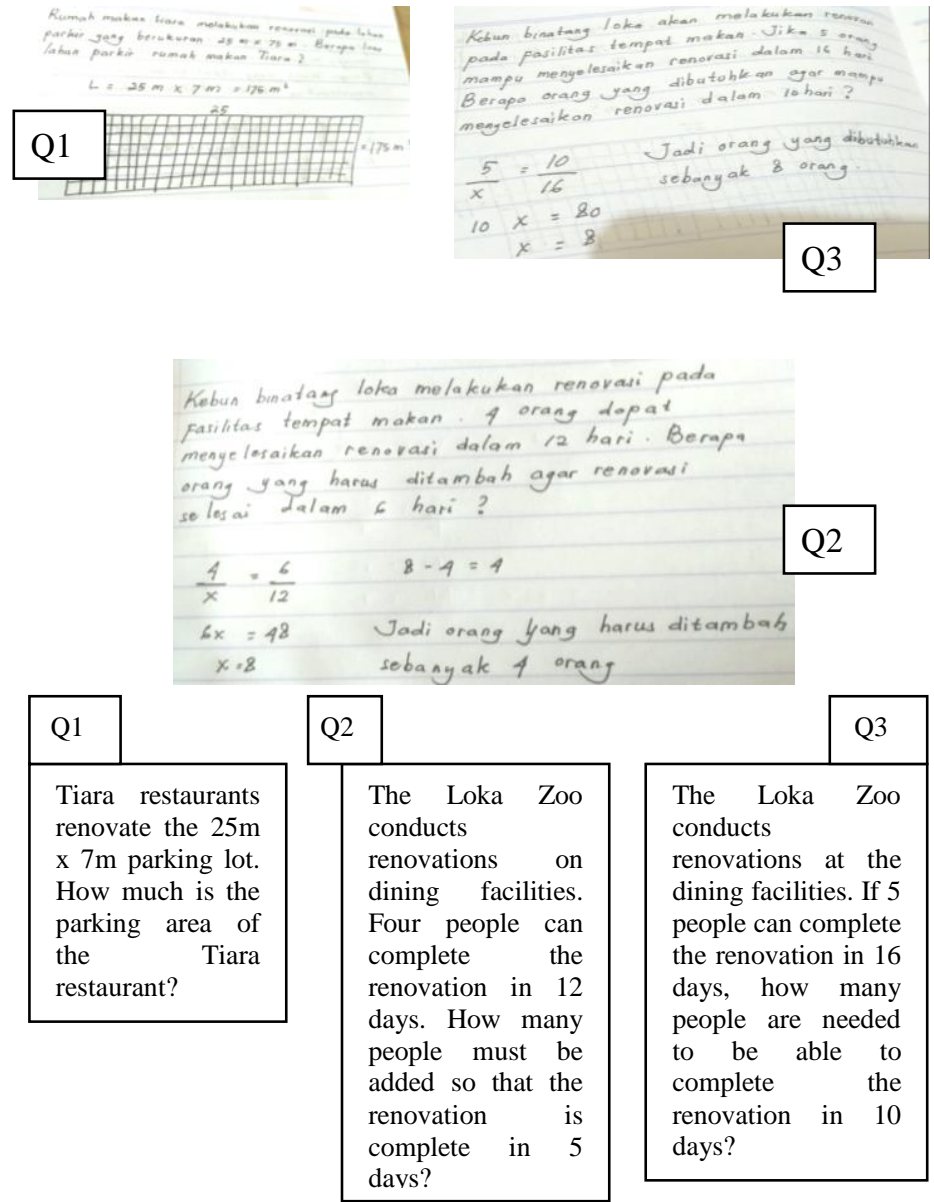

Figure 3: Problems and Solutions Posed by Student in Occupational Context

The student posed the first question about the area to be renovated. The area posed by students was rectangular. Student completed the problems in two different ways. The first way used $(p \times l)$ formula while the second way by describing the rectangle. Student divided the rectangle into a square arrangement, with a length of 25 units and a width of 7 units. Both answers were correct. Therefore, the first question (Q1) met the flexibility.

Student posed the second and third questions with the concept of turning comparison. Student posed the questions by changing the subject and the number. The difference between the second question $(\mathrm{Q} 2)$ and third question $(\mathrm{Q} 3)$ was in the use of the sentence context. The second question $(\mathrm{Q} 2)$ focused on counting the officer to be added while the third question (Q3) counted the total of required officers. Students did this problem only using one way. The student's answer was correct. The story question based on occupational context was CTL 3 because it met components of fluency and flexibility. 


\section{Student in Scientific Context}

A Student in scientific context posed three problems and solution shows in Figure 4.

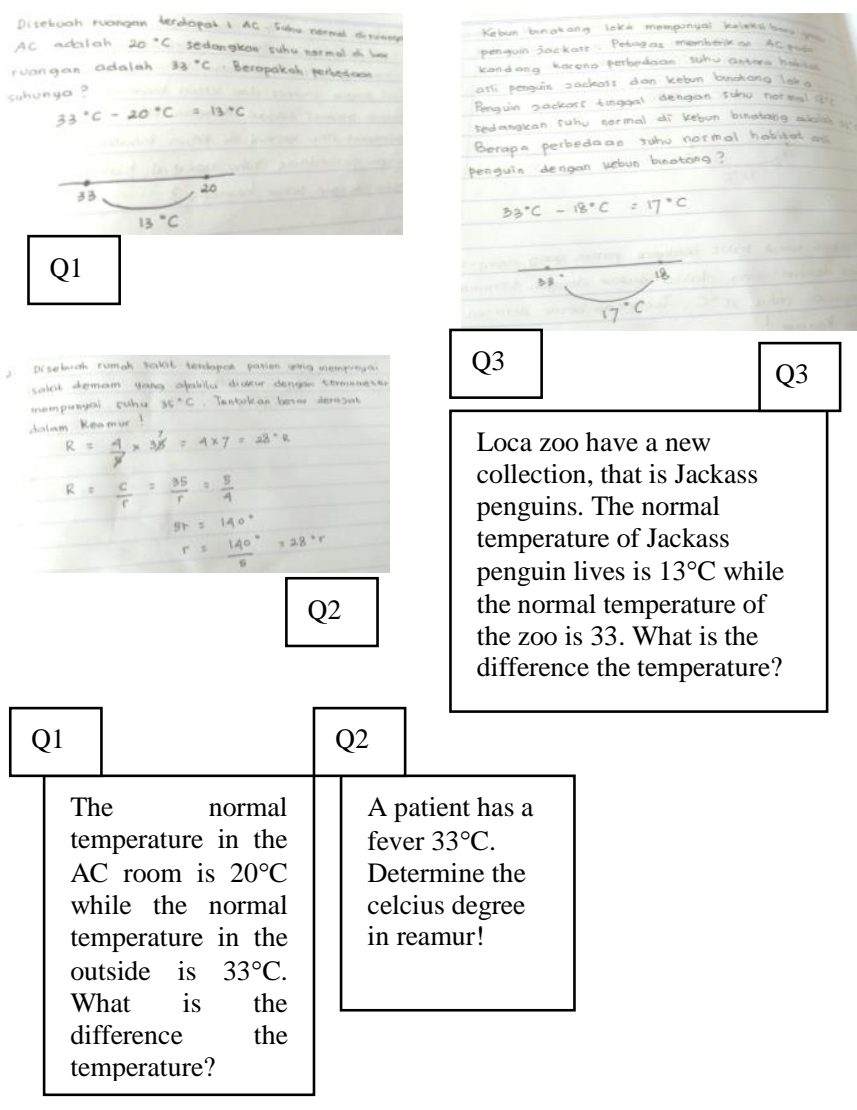

Figure 4: Problems and Solutions Posed by Student in Scientific Context

Student posed the first story question (Q1) about the difference of temperature in the two places. Student changed the subject and the numbers and eliminated some information on the initial problem. The concept used by students was integer. Students answered the question in two different ways by using the reduction of integers and number lines. So, the first question (Q1) met component of flexibility. Student posed the second question (Q2) about temperature conversion from Celsius to Reamur. The concept used was a comparable comparison. Student changed information of the initial story question about so that it met the component of novelty. Student solved the problem using only one way so that it did not meet the component of flexibility.

Student posed the third question (Q3) about temperature changes. The information was different from the first question even though the concept used was the same. In the third question, student posed the questions by changing subject and numbers. Student solved the problem in two ways, namely using the nature of the reduction of integers and number lines. The answer was correct, so that third question met the component of flexibility. The question based on scientific context was CTL 4 because it met all the components.

\section{DISCUSSION}

The components of creative thinking skills in posing the problems were fluency, flexibility, and novelty [15]. Fluency was seen when students made at least three different questions. Flexibility was seen from the numbers of solution used in several ways. The novelty was seen from different concept in solving the problem [15]. Student who posed the story question in the societal context only fulfilled the fluency component because it changed only the subject and the numbers so that it met CTL1. The question based on personal context met CTL 2 because it had novelty component even though only making two submissions question.

Even though the students posed more story questions based on societal context, but only changing the subject and the number so it can be categorized in CTL 1 with component of fluency. While, student could achieve higher CTL if creating new problems that met the component of novelty. Student who was given story question based on occupational context did not meet the novelty component but at least one problem was solved in a different way so as that it met the component of flexibility

\section{CONCLUSION}

Based on the results of the study, we conclude that the creativity of students in posing the problem depends on the familiarity of context. More students posed personal context than other context. Even though depend on the familiarity of context, more students posed the questions by changing subject and numbers only. Students could achieve higher CTL if creating at least one new problems or solving at least one problem in a different way.

\section{ACKNOWLEDGEMENT}

This research reported here in was supported by Junior High School of SMP Al Islamiyah, Sidoarjo. The opinions expressed herein do not necessarily reflect the position, policy, or endorsement of the supporting agency.

\section{REFERENCES}

[1] I. K. Amalina, M. Amirudin, and M. T. Budiarto, "Student's Creativity: Problem Posing in Structured Situation", Journal of Physics, 2017.

[2] H. A. R. Tilaar, Pengembangan Kraetivitas dan Enterpreneurship, Jakarta: Kompas, 2012.

[3] J. Y. F. Lau, An Introduction to Critical Thinking and Creativity Think More, Think Better, New York: Wiley-Interscience, 2011.

[4] R. Lince, "Creative Thinking Ability to Increase Student Mathematical of Junior High School by Appling Models Numbered Head Together", Journal of Education and Practice, vol.7, no. 6, pp. 206 - 212, 2016.

[5] G. Polya, How to Solve It, Princeton: Princeton University Press, 2004.

[6] T. Y. E. Siswono and I. K. Budayasa, "Implementasi Teori tentang Tingkat Berpikir Kreatif dalam Matematika", Seminar Konferensi 
Nasional Matematika XIII dan Konggres Himpunan Matematika Indoneisa, pp. 1 - 16, 2006.

[7] E. E. Arikana and H. Unal, "Investigation of Problem-Solving and Problem-Posing Abilities of Seventh-Grade Students", Educational Sciences: Theory \& Practice, 2015.

[8] T. Mukuthan, “A Study On Student's Error On Word Problem", International Journal of Management, IT, dan Engineering, vol. 3, no. 10, pp. $205-14,2013$.

[9] T. Y. E. Siswono, "Upaya Meningkatkan Kemampuan Berpikir Kreatif Siswa Melalui Pengajuan Masalah", Jurnal Pendidikan Matematika dan Sains, vol. 10, no. 1, pp. $1-9,2005$.

[10] M. Rahardjo and A. Waluyati, Pengembangan Soal Cerita Operasi Hitung Campuran di Sekolah Dasar, Yogyakarta: Pusat Pengembangan dan Pemberdayaan Pendidik dan Tenaga Kependidikan Matematika, 2011.
[11] M. Van de Heuvel-Panhuizen, "The Role Contexts in Assessment Problems in Mathematics", For Learning of Mathematics, vol. 2, pp. 2 9, 2005.

[12] L. P. Cheng, "The Design of a Mathematics Problem Using Real-Life Context for Young Children", Journal of Science and Mathematics Education in Southeast Asia, vol. 36, no.1, pp. 23 - 43, 2013.

[13] F. A. Salgado, "Developing a Theoretical Framework for Classifying Levels of Context Use for Mathematical Problems", Proceedings of the $39^{\text {th }}$ annual conference of Mathematics Education Research Group of Australia, Adelaide, pp. 110 - 117, 2016.

[14] OECD, PISA 2015 Assessment and Analytical Framework: Mathematics. Reading, Science, Problem Solving and Financial Literacy, Paris: OECD, 2016.

[15] E. A. Silver, "Fostering Creativity Through Instruction Rich in Mathematical Problem Solving and Problem Posing”, ZDM, vol. 29, pp. $75-80,1997$. 